\title{
Souvenir Bullet Recovered From Firearm Victim: Case Report
}

\author{
Luv Sharma*, A. D. Aggarwal and P. K. Paliwal
}

Department of Forensic Medicine, University of Health Sciences, Haryana, India

\begin{abstract}
Firearm injuries are commonly encountered by Forensic pathologists. The autopsy technique for a firearm case requires special care as the projectile has to be removed as evidence. Not all firearm injuries result in death. Survivors may carry bullets in their bodies for long periods of time as souvenirs. Souvenir or retained bullets may sometimes cause diagnostic problems regarding old or recent firearm wounds. We present a case of a firearm fatality in which a souvenir bullet was found during autopsy in a firearm victim.
\end{abstract}

Keywords: Firearms; Bullets; Souvenir; Retained; Artifacts; Autopsy

\section{Introduction}

If a bullet remains embedded in the body for a long time, it is termed as a souvenir bullet. ${ }^{1}$ Bullets can be lodged in bone or soft tissue in any firearm incident without causing any serious damage or may be located in an area where surgical removal could prove fatal. It is advisable to leave the bullet as such if it is too dangerous to manipulate or if it is lodged in an innocuous area without any potential risk or complication.

Foreign bodies such as bullets can remain silent for a long period of time without giving rise to clinical symptoms. It is important for the surgeon to consider removal of a foreign body/bullet only if there is a serious health hazard, keeping in mind the possibility of causing a pathologic fracture. [2]

Souvenir bullets are recognized by fresh bleeding in and around with dense fibrous capsule surrounding them. A small old scar will suggest the original entry wound of the bullet [2]. In the investigations of cases of gunshot wounds, the findings of unexpected bullets in the body are always a puzzle and may lead to false conclusions. Abdullah Fateh reports an example of an 'old bullet' in a severely burnt dead body. $\mathrm{X}$-rays showed a bullet in the posterior wall of the chest. This $\mathrm{X}$-ray finding immediately raised suspicions of murder. However, when the bullet was localized and removed, it was found to be well wrapped with dense fibrous tissue. In another case a 'new' bullet formed an artifact. A man shot himself in the right temple and the bullet was recovered from the brain. There was, however, another bullet in the stomach. The scene investigation showed a row of beer cans in the man's backyard, used as targets. Part of the beer in the cans that had bullet holes had been consumed. It is surmised that the man drank beer from each can he shot successfully and 'drank' a bullet with the beer [3].

A decomposed dead body of an unidentified male was recovered from a canal; the police suspected foul play and the body was brought for post-mortem examination. The crime scene (the canal and its vicinity) showed no clue regarding identity of the victim nor did anyone from neighboring villages recognize him.

\section{Autopsy findings}

At autopsy, the age was found out to be between 35-40 years. An entry wound of firearm of size $1 \times 0.5 \mathrm{~cm}$ was noted on the left side of the face, $3.5 \mathrm{~cm}$ from lateral angle of left eye \& $164 \mathrm{~cm}$ above left heel. The margins of this wound were irregular, reddish and inverted with abraded collar in the form of an arc of size $5 \mathrm{~mm}$, more on the medial and inferior aspects. The wound was directed from left to right and posteriorly to pierce the skull, dura and lacerate the brain to emerge out as the exit wound. The exit wound was of size $0.7 \times 0.5 \mathrm{~cm}$ situated over right temporal area. There was shattering of the involved cranial bones in its path. (Figure 1).

On dissection of the thorax, reflection of skin on the left side revealed a bullet embedded in the musculature of the thoracic wall, just below the inferior border of the left clavicle. (Figure 2) The area of this embedment was dark red in colour, ovalish and slightly depressed; it was $1 \times 0.5 \mathrm{~cm}$ in size, situated $9 \mathrm{~cm}$ from the midline and $11 \mathrm{~cm}$ from the tip of the left shoulder. There was fibrosis around the bullet in the form of a fibrous capsule. On the reflected skin flap (inner surface) a similar depressed and dark red coloured area was noted corresponding

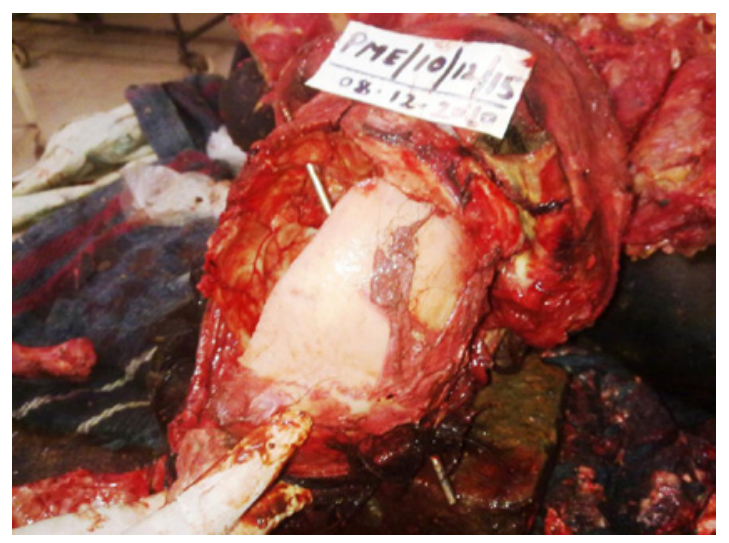

Figure 1: Track of head wound caused by bullet.

*Corresponding author: Dr. Luv Sharma, Professor, Department of Forensic Medicine, University of Health Sciences, 24/9-J, Medical Enclave, Rohtak-124001, Haryana, India, Tel: 91-1262-213165/ 91-9416101258; E-mail: drluvksharma@ yahoo.com

Received January 08, 2011; Accepted March 15, 2011; Published March 25 , 2011

Citation: Sharma L, Aggarwal AD, Paliwal PK (2011) Souvenir Bullet Recovered From Firearm Victim: Case Report. J Forensic Res 2:121. doi:10.4172/21577145.1000121

Copyright: (C) 2011 Sharma L et al. This is an open-access article distributed under the terms of the Creative Commons Attribution License, which permits unrestricted use, distribution, and reproduction in any medium, provided the original author and source are credited. 


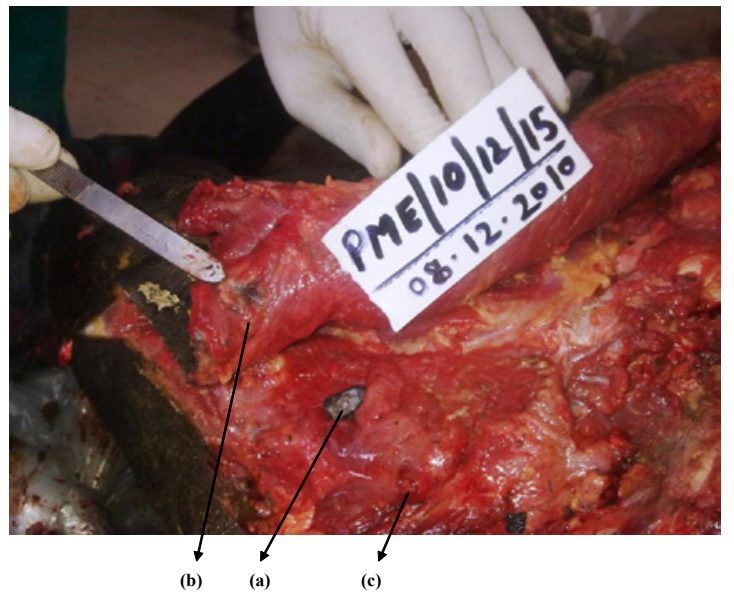

Figure 2: Souvenir bullet embedded in thoracic wall (b); the depressed and dark red coloured area on inner reflected flap of skin (c) \& fibrous tissue and depression with capsule like appearance marking site of embedment.

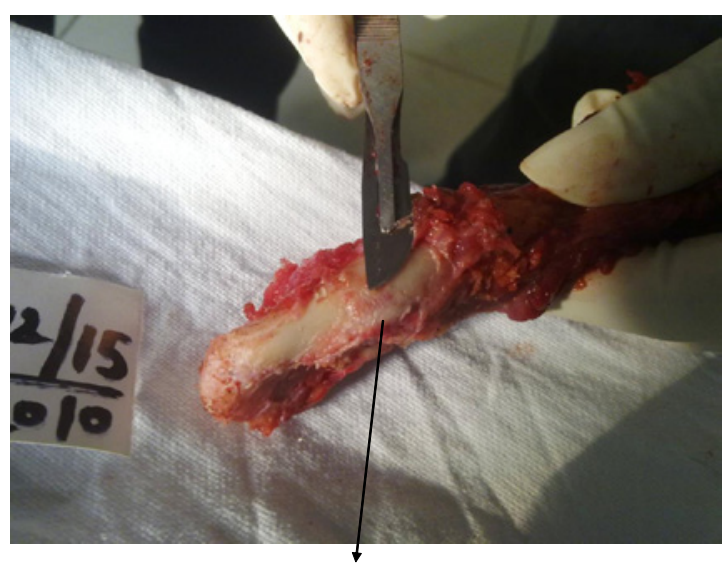

Figure 3: The inferior border of the left clavicle in its medial aspect grazed with slightly indented and rugged surface.

to the above mentioned finding. The external (skin) surface i.e. left chest wall showed evidence of an old wound, ovalish in shape in the form of a hypo pigmented rugged area. The inferior border of the left clavicle in its medial aspect was found to be grazed with slightly indented and rugged surface. (Figure 3) The musculature surrounding this area was dark reddish with evidence of effusion on dissection. The bullet was 1 x $0.5 \mathrm{~cm}$ in length with vertical lines on its long surface, indicative of being fired from a country made/improvised firearm. The bullet was sent for ballistic analysis.

\section{Ballistic analysis results}

Ballistic analysis of the souvenir bullet was carried out in the State Forensic Science Laboratory. The bullet was identified to be a 303 bullet fired from an improvised country made firearm with 315 bore (called Katta in Northern India) by the primary markings on its long side. The report also opined that the weapon used must have had a very low wounding capacity as it merely had entered the chest wall lodging just below the inferior border of the clavicle and had not been able to cross the ribcage.

\section{Discussion}

'Surgeon in Hot Water for Keeping Souvenir Bullet From
Patient'- this catchy news item appeared recently regarding a Florida Surgeon. The doctor, was convicted of withholding evidence from law enforcement received a 10-day suspension without pay. He had found a bullet while performing surgery on a man who was shot by a deputy U.S. marshal and took the bullet out of the patient's abdomen and put it in his pocket [4].

With sufficient force (as in firing of bullets), a foreign body can become lodged into nearly any tissue including bones. Some foreign objects remain isolated by encapsulating themselves with a granulation tissue reaction and pose very little danger. Embedded lead particles are usually considered inert after their kinetic energy has dissipated hence these are not removed routinely. Removal is indicated if they impinge on vital structures or are easily accessible during operation for other reasons. [5] Soft and absorbable foreign substances are gradually dissolved and taken up by the tissue cells. Compact and insoluble foreign bodies are shut in by new-formed tissue, which is slowly transformed into a fibrillar connective-tissue capsule, gradually shutting the foreign body off from contiguity with the organism. If the foreign body is hollow or porous, the new tissue grows into it and separates it from the rest of the tissue on the inner as well as the outer surface [6].

Souvenir bullets have been reported in Medical literature from time to time some cases involving some famous personalities. One of the most celebrated souvenir bullet owners was the Soviet leader Vladimir Lenin. In January 1918 an assassination attempt was made against Lenin but he wasn't injured. Another attempt was made in August and this time he was shot in the arm and the juncture of his jaw and neck. Doctors were called because Lenin refused to go the hospital but didn't remove the bullets because it was too dangerous. The bullet in his neck caused health problems later in life but was too close to his spine for doctors at the time to remove. Another famous person associated with souvenir bullets was Theodore Roosevelt the 26th President of the United States. In 1912 he was shot in the chest but the bullet first passed through both his steel eyeglass case and his 50 page speech. He went on to deliver the 90-minute speech and carried the bullet, which was three inches in his chest, for the rest of his life [7].

Interestingly, there is a debate regarding removal of the bullet retained by the U.S. President James Garfield who was shot and battled for life for 80 days before his death. In Garfield's day doctors would probe gunshot wounds in the belief that if they could remove the bullet everything would be fine. Garfield's real problem was the ill-advised, ill-directed poking with non-sterile instruments by every doctor who entered the sickroom. All that meddling introduced more bacteria into Garfield's body. When the doctors finally located the bullet during an autopsy on Garfield's body, they found it lodged in the back muscle-a far less dangerous place than they had thought. During his trial Charles Guiteau, the assassin, claimed he hadn't killed the President, the doctors had. He probably was right [8].

\section{References}

1. Karmakar RN, Mukherjee JB (2007) Forensic Medicine and Toxicology $3^{\text {rd }}$ edition Academic publishers Kolkatta 396.

2. Fernandes FA, Fernandes A (2007) Bullets in the mandible over 12 years: a case report. British Dental 202: 399-401. 
Citation: Sharma L, Aggarwal AD, Paliwal PK (2011) Souvenir Bullet Recovered From Firearm Victim: Case Report. J Forensic Res 2:121. doi:10.4172/2157-7145.1000121

Page 3 of 2

3. Fatteh A (1976) Recognition of artefacts. In Medico-legal investigation of gunshot wounds. JB Lippincott company Philadelphia 177.

4. Rehman1 MA, Umer M, Sepah YJ, Wajid MA (2007) Bullet-induced synovitis as a cause of secondary osteoarthritis of the hip joint: A case report and review of literature. Journal of Medical Case Reports 1: 171.

5. Martin W. Annsurg00788-0032.pdf. The significance of foreign bodies in the tissues. Read before the New York Surgical Society, October I3, I9I5.
6. Polson K (2009) Surgeon in Hot Water for Keeping Souvenir Bullet From Patient. The Oracle, U. South Florida. http://www.foxnews.com/ story/0,2933,555442,00.html

7. http://pakway.blogspot.com/2009/11/shot-50-famous-people-who-have-taken. $\mathrm{html}$

8. http://ask.metafilter.com/73088/Why-is-it-so-important-to-remove-the-bullet. 